\title{
In memoriam: Sulejman Redžić
}

\author{
Sjećanje: Sulejman Redžić
}

\author{
Vlado Matevskil ${ }^{*}$, Andraž Čarni²
}

Macedonian Academy of Sciences and Arts, Skopje, Krste Misirkov 2, 1000 Skopje; Republic of North Macedonia; Faculty of Natural Sciences
and Mathematics, Ss. Cyril and Methodius University, Skopje, Republic of North Macedonia
2 Macedonian Academy of Sciences and Arts, Skopje, Krste Misirkov 2, 1000 Skopje; Republic of North Macedonia; Research Center of the
Slovenian Academy of Sciences and Arts, Institute of Biology, Ljubljana, Slovenia

Honourable Chairperson,

Respected academicians, professors, students,

Dear friends,

Today, we have gathered here to remind ourselves and to note that for 5 years now there is not among us, our dear colleague, friend, excellent scientist, great man, professor and academician Sulejman Redžić.

Our joint address (together with colleague Andraž Čarni from Ljubljana) is an expression of our deep respect for the man with whom we shared some period of joint scientific work on studying the flora and vegetation of the Balkan peninsula, pleasant socializing, botanical collegiality and sincere friendship.

More than 5 years ago, we could not believe or accept the sad news published by the media that Sulejman Redžić had been suffered in the snowy Miljacka canyon above Sarajevo on January 7,2013.This feeling is still present, because whenever we came to Sarajevo, our first thought was to meet Suleiman first. The news of his death was also hit the participants of the symposia about the vegetation of Europe, which was held that year in Rome, where Andraž Čarni exposed several facts about his work and life. Thus one of the important and respected Balkan vegetation experts disappeared from the scientific community, which would play an important role in creating the synthesis of European vegetation, which was then in the final stage of preparation (published 2016).
I knew Sulejman and his wife Amira for over 30 years. Together, we were professional beginners as botanical assistants at the Universities in Sarajevo and Skopje.

It was a time when we met more often, cooperated and interacted during the various conferences and symposia of ecologists, biologists, biosystematics of former Yugoslavia (in Sarajevo, Budva, Ohrid, Gozd Martuljek, Ljubljana, Zabljak and other places).

Later, the disintegration of Yugoslavia and all that resulted from this decomposition, our communication never been interrupted, even during the war in Bosnia and Herzegovina. We regularly wrote to each other and sent letters in that unfortunate time through various channels. I kept his letters from the demolished Sarajevo from that period, where Sulejman and his family suffered in that terrible period of war, an unprecedented senseless thing that happened in this region.

After everything that happened, he was optimistic that the situation in Bosnia and Herzegovina would still improve, so that his entire engagement was directed in that direction. He wanted that much lost in that unfortunate period as soon as possible upgrade, to restore cooperation between the institutions of the former Yugoslavia, organize meetings, establish interrupted contacts with colleagues, etc.

I recall that during my stay in Ljubljana (2000) at the Biological Institute "Jovan Hadži” of the Slovenian Academy of Sciences and Arts, my colleague Andraž Čarni received a mail message from Sulejman with an invitation to visit

* Corresponding author:Vlado Matevski Macedonian Academy of Sciences and Arts, Skopje, Krste Misirkov 2, I000 Skopje; Republic of North

Macedonia; e-mail address: vlado.matevski@yahoo.com 
him in Sarajevo. We did not think for a long time, so we visited him with colleagues Andraž Čarni and Mitko Kostadinovski, on August 28 and 29, 2000 in Sarajevo. We slept at his house and we were one day on a fieldtrip near Sarajevo in the direction of Pale, where we collected the plants and where the minefields were marked on the field where we were botanized. On the way to Sarajevo, as Sulejman recommended to us the day before departure to Sarajevo, we started from Ljubljana to Bihać, and via AVNOJ motorway to Jajce and Sarajevo.

Sulejman, knowing our botanical curiosity, warned us not to collect plants near the road, as many of the terrain was still mined. He wrote to us not to be fooled by the fact that where we see sheep in the pastures they are safe places for botanists. Because the weight of the sheep, he has been warned us sometimes it is not enough to activate the mined terrain. He took care of everything to safely we reach Sarajevo.

Later, from 18 to 24 May 2003, he successfully organized the Third Balkan Botanical Congress in Sarajevo, where the botanists from the Balkans were together again in Sarajevo and Bosnia and Herzegovina, where they formed a park of Balkan friendship in the Faculty of Natural Sciences and Mathematics.All botanists from the Balkans planted a tree, so we hope that this park is still being maintained.

Last time together with Sulejman we were in Žabljak, Montenegro (19-24.09.20II) at the celebration of the 50th anniversary of the Republic Institute for the Protection of Nature of Montenegro. There we spent several unforgettable days where Sulejman was the main promoter and animator of the program of that event.

Much has been said about Sulejman, but it is certainly not enough in relation to how much he deserved. He had so much energy and ideas, during the lectures, field trips, projects, and his social engagement. He was the Dean of the Faculty of Natural Sciences and Mathematics in Sarajevo, Deputy Minister in the Ministry of Environment of Bosnia and Herzegovina, member of the Academy of Sciences and Arts of Bosnia and Herzegovina and others.

Sulejman Redžić was an engaged intellectual, patriot, but above all botanist-ecologist, founder of the Centre for Ecology and Natural Resources - Faculty of Natural Sciences and Mathematics in Sarajevo, who throughout his life studied the unique biodiversity of Bosnia and Herzegovina. He was one of the leading Balkan ecologists, a creative and tireless researcher who with the maturity of his scientific achievements contributed to the affirmation of the Bosnian and Balkan botanical science on the international scene.
With his scientific work he has made a significant contribution to the knowledge of the flora and vegetation of our area, primarily the genus Potentilla, Edrianthus, high mountain vegetation, vegetation of dry grasslands and forest vegetation. His achievements represent a significant contribution to the knowledge of the flora and vegetation in the wider Balkan region and will remain part of the remarkable knowledge of biodiversity, where researchers in the region and beyond will continue to be upgraded.

One thing is certain, people like Sulejman Redžić are very rare. We are all proud of his work.

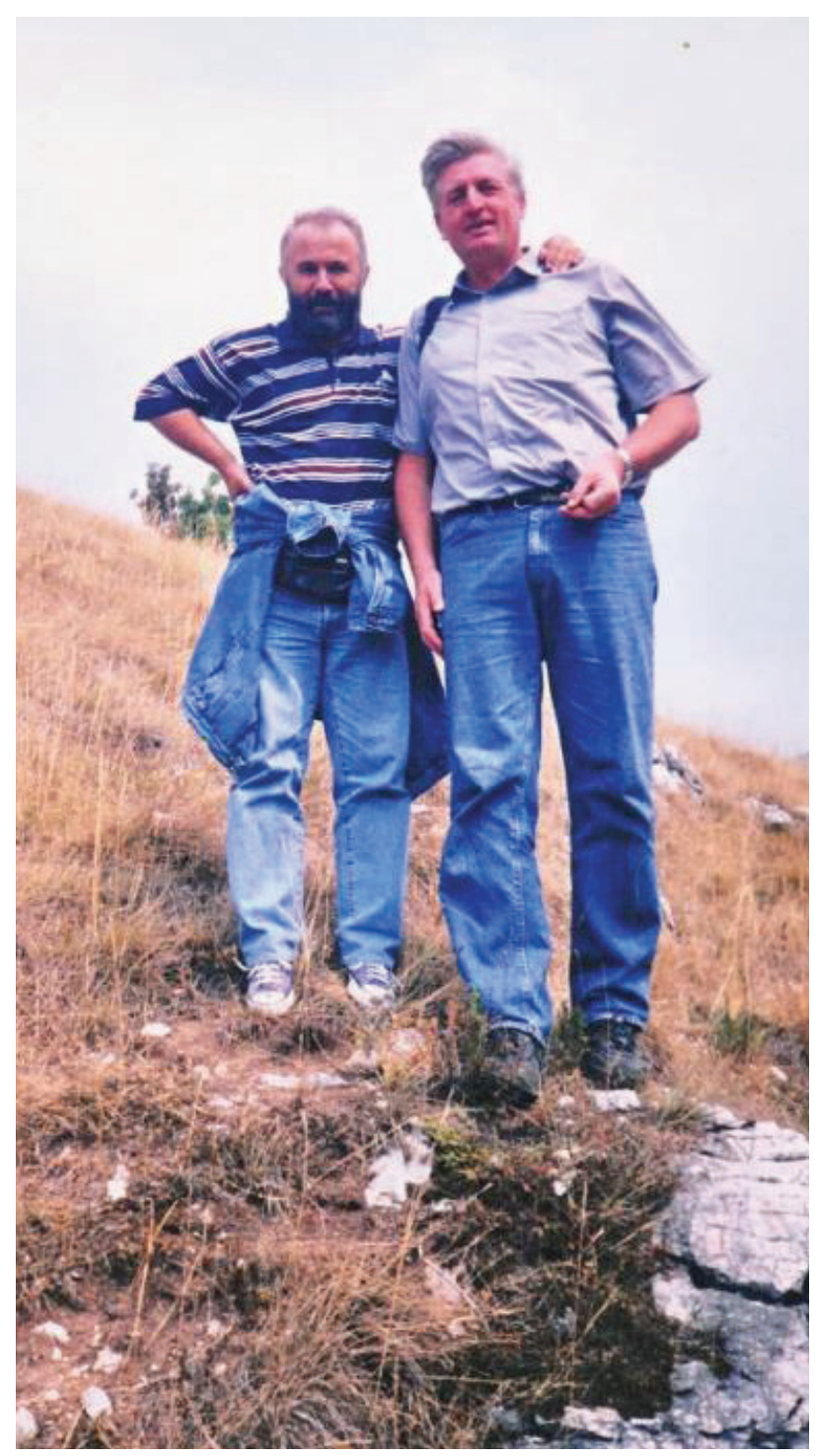

Figure I. Sulejman Redžić and Vlado Matevski field trip in the surroundings of Sarajevo (29.08.2000.)

Slika I. Sulejman Redžić i Vlado Matevski obilazak terena u okolini Sarajeva (29.08.2000.) 


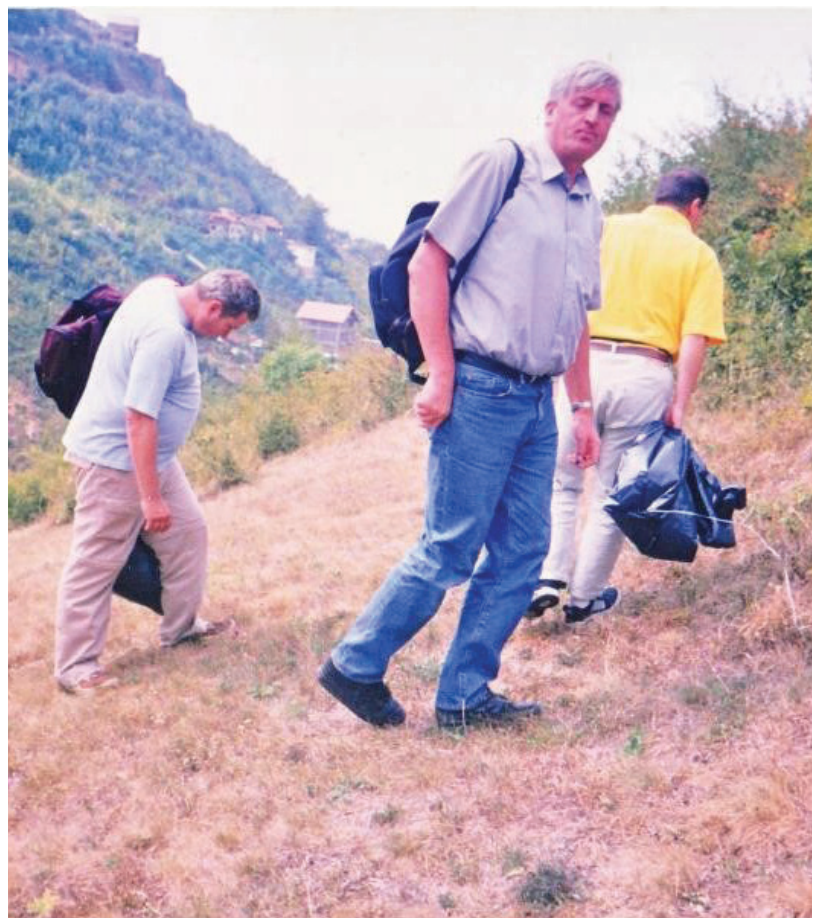

Figure 2. Sulejman Redžić, Andraž Čarni and Mitko Kostadinovski - field trip in the surroundings of Sarajevo (29.8.2000)

Slika 2. Sulejman Redžić, Andraž Čarni i Mitko Kostadinovski obilazak terena u okolini Sarajeva (29.08.2000.)

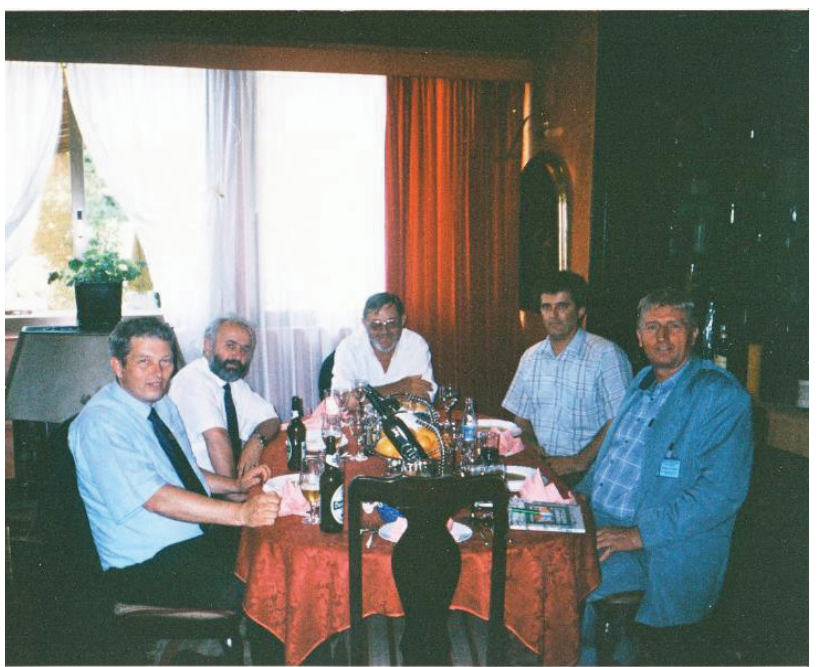

Figure 3.Third International Balkan Botanical Congress, Sarajevo, 24.05.2003 (Andraž Čarni,Vlado Matevski,Andrija Lovrić, Zlatko Bulić, Sulejman Redžić)

Slika 3.Treći Međunarodni Balkanski Botanički Kongres, Sarajevo, 24.05.2003 (Andraž Čarni,Vlado Matevski, Andrija Lovrić, Zlatko Bulić, Sulejman Redžić)

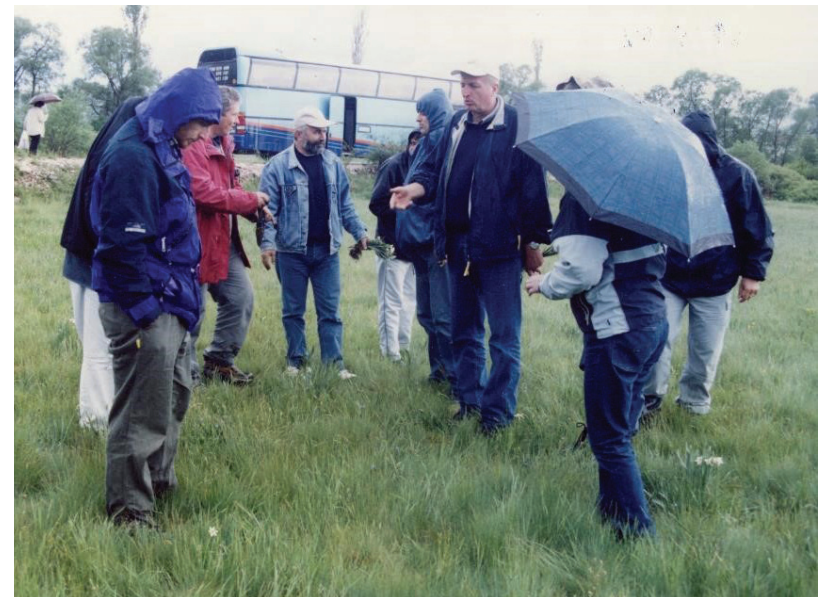

Figure 4. Field trip, Posušje, Hercegovina - Participants of the Third International Balkan Botanical Congress, Sarajevo, 21 .05.2003.

Slika 4. Ekskurzija, Posušje, Hercegovina - Učesnici Trećeg Međunarodnog Balkanskog Botaničkog Kongresa, Sarajevo 21.05.2003.

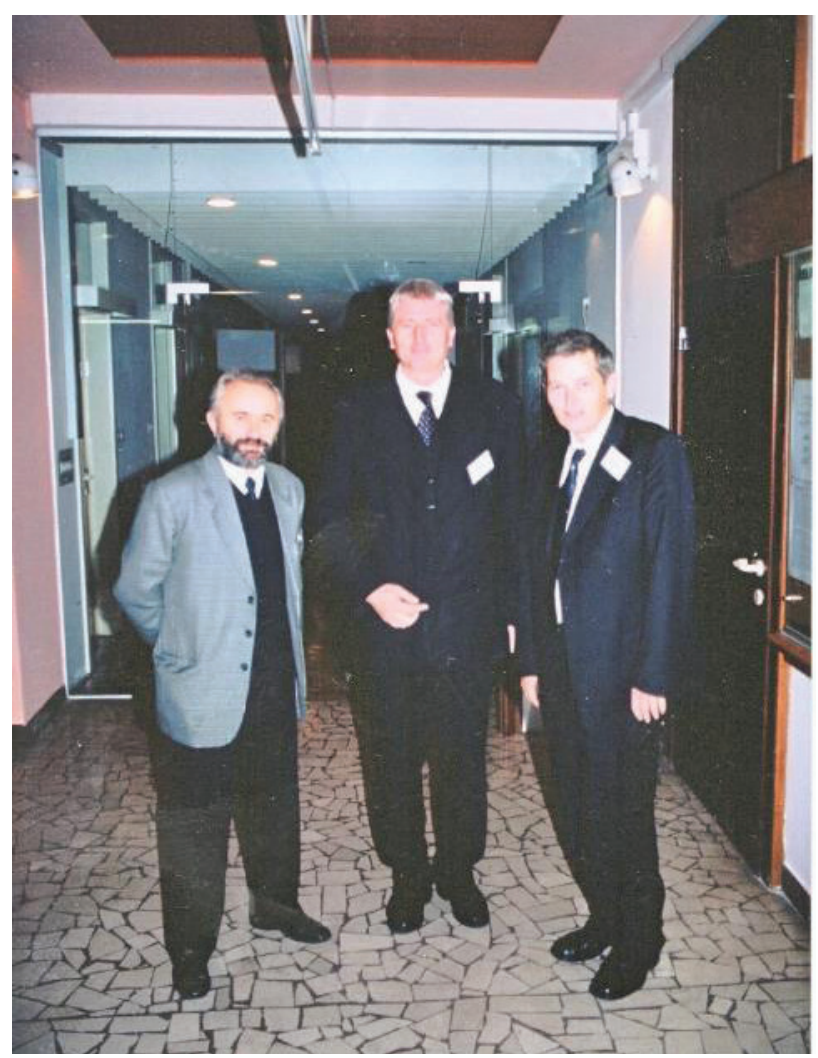

Figure 5. Simpozium devoted to 80 anniversary of Alojz Šecelj and 70 anniversary of Mija Zupančič and Lojze Marinček, Ljubljana, 21.II.200I (Vlado Matevski, Sulejman Redžić and Andraž Čarni)

Slika 5. Simpozijum posvećen 80-toj godišnjici Alojza Šecelja i 70 godina Mije Zupančiča i Lojze Marinčeka, Ljubljana 21.I I.200I. (Vlado Matevski, Sulejman Redžić i Andraž Čarni) 


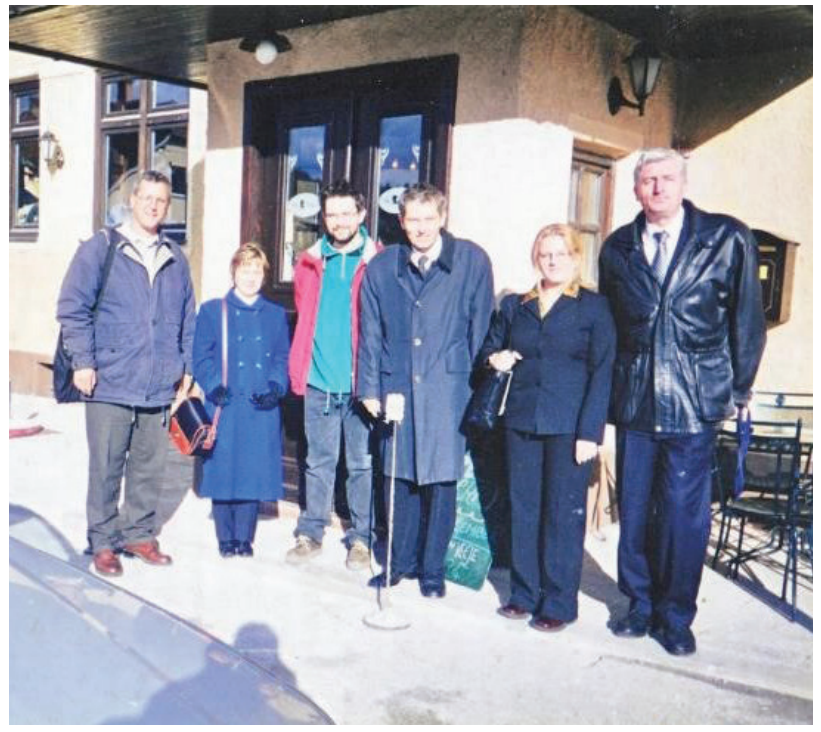

Figure 6. Simpozium devoted to 80 anniversary of Alojz Šecelj and 70 anniversary of Mija Zupančič and Lojze Marinček, Ljubljana, 2I.I I.200 I (Participants: Juraj Kamenjarin, Božena Mitić, Nejc Jogan, Andraž Čarni, Urška Sodec, Sulejman Redžić)

Slika 6. Simpozijum posvećen 80 godina Alojza Šecelja i 70 godina Mije Zupančiča i Lojze Marinčeka, Ljubljana 21.I I.200I. (Učesnici: Juraj Kamenjarin, Božena Mitić, Nejc Jogan, Andraž Čarni, Urška Sodec, Sulejman Redžić)

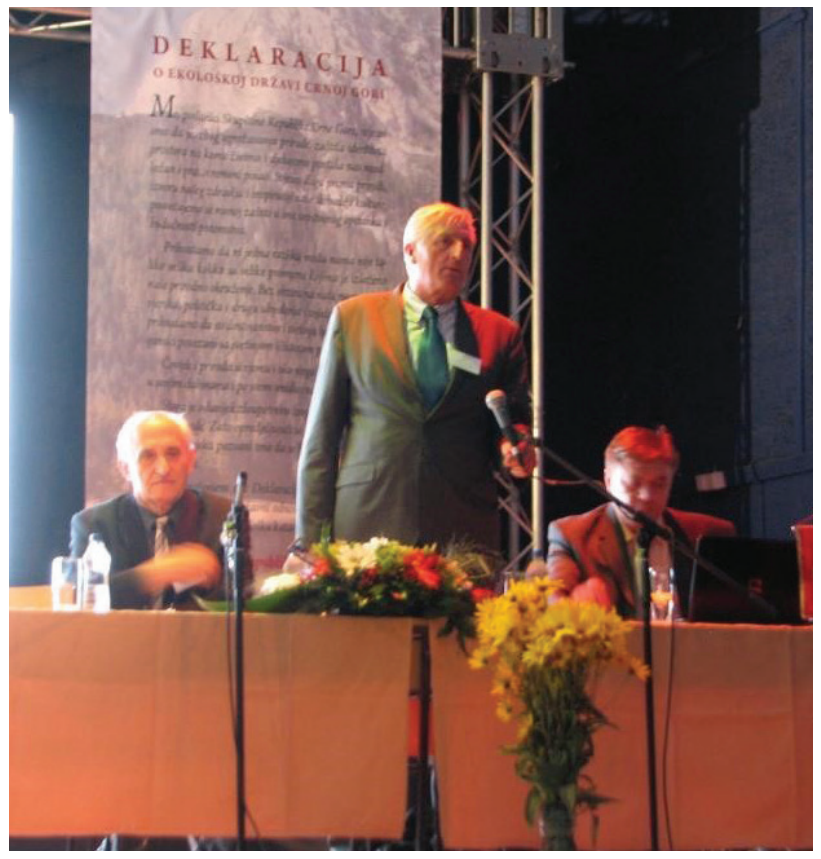

Figure 7. Žabljak, Montenegro (20.09.20I I) - Vukić Pulević, Sulejman Redžić and Vasilije Bušković at the celebration of the $50^{\text {th }}$ anniversary of the Republic Institute for the Protection of Nature of Montenegro (19-24.09.20II)

Slika 7. Žabljak, Crna Gora (20.09.20I I) - Vukić Pulević, Sulejman Redžić iVasilije Bušković na proslavi 50 godina Republičkog Instituta za zaštitu prirode Crne Gore (19-24.09.20I I)
Poštovani predsedavajući,

Poštovani akademici, profesori, studenti,

Dragi prijatelji,

Danas smo se okupili ovdje da se podsjetimo i primijetimo da već pet godina među nama nema našeg dragog kolege, prijatelja, vrsnog naučnika, velikog čovjeka, profesora i akademika Sulejmana Redžića.

Naše zajedničko obraćanje (zajedno sa kolegom Andražom Čarnijem iz Ljubljane) izraz je našeg dubokog poštovanja prema čovjeku s kojim smo dijelili neko razdoblje zajedničkog naučnog rada na proučavanju flore $\mathrm{i}$ vegetacije Balkanskog poluostrva, ugodnom druženju, botaničkoj kolegijalnosti i iskrenom prijateljstvo.

Prije više od 5 godina nismo mogli vjerovati niti prihvatiti tužnu vijest koju su mediji objavili da je Sulejman Redžić stradao u snježnom kanjonu Miljacke iznad Sarajeva 7. januara 20I3.Taj osjećaj je i dalje prisutan, jer kad god smo došli u Sarajevo, prva misao nam je bila da prvo upoznamo Sulejmana.Vijest o njegovoj smrti pogodila je i učesnike simpozijuma o vegetaciji Evrope, koji je te godine održan u Rimu, gdje je Andraž Čarni izložio nekoliko činjenica o svom radu i životu. Tako je jedan od važnih i cijenjenih balkanskih stručnjaka za vegetaciju nestao iz znanstvene zajednice, što bi igralo važnu ulogu u stvaranju sinteze evropske vegetacije, koja je tada bila u završnoj fazi pripreme (objavljeno 2016.).

Sulejmana i njegovu suprugu Amiru poznavao sam preko 30 godina. Zajedno smo bili profesionalni početnici kao botanički asistenti na univerzitetima u Sarajevu i Skoplju.

Bilo je to vrijeme kada smo se češće susretali, sarađivali i komunicirali tokom raznih konferencija i simpozijuma ekologa, biologa, biosistematike bivše Jugoslavije (u Sarajevu, Budvi, Ohridu, Gozdu Martuljku, Ljubljani, Žabljaku i drugim mjestima).

Kasnije, raspadom Jugoslavije i svime što je proizašlo iz ovog raspada, naša komunikacija nikada nije bila prekidana, čak ni tokom rata u Bosni i Hercegovini. Redovno smo pisali jedni drugima i slali pisma u to nesretno vrijeme raznim kanalima. Čuvao sam njegova pisma iz srušenog Sarajeva iz tog razdoblja, gdje su Sulejman i njegova porodica stradali u tom strašnom ratnom periodu, besprimjerna besmislena stvar koja se dogodila na ovim prostorima.

Nakon svega što se dogodilo, bio je optimista da će se situacija u Bosni i Hercegovini još poboljšati, tako da je 
čitav njegov angažman bio usmjeren u tom smjeru. Želio je da se toliko izgubljenog u tom nesretnom periodu što prije nadogradi, da se obnovi saradnja između institucija bivše Jugoslavije, organizuju sastanci, uspostavljaju prekinuti kontakti sa kolegama itd.

Podsjećam da je za vrijeme mog boravka u Ljubljani (2000.) na Biološkom institutu "Jovan Hadži” Slovenske akademije nauka i umjetnosti, moj kolega Andraž Čarni dobio Sulejmanovu poruku sa pozivom da ga posjeti u Sarajevu. Nismo dugo razmišljali, pa smo ga posjetili sa kolegama Andražem Čarnijem i Mitkom Kostadinovskim, 28. i 29. avgusta 2000. godine u Sarajevu. Spavali smo u njegovoj kući a jedan dan smo bili na izletu u blizini Sarajeva u pravcu Pala, gdje smo sakupljali biljke pored mjesta označenih kao minska polja. Na putu za Sarajevo, kako nam je preporučio Sulejman, krenuli smo od Ljubljane do Bihaća, a autoputem AVNOJ-a do Jajca i Sarajeva.

Sulejman, znajući našu botaničku radoznalost, upozorio nas je da ne sakupljamo biljke u blizini puta, jer je većina terena još bila minirana. Pisao nam je da se ne zavaravamo činjenicom da mjesta gdje vidimo ovce na pašnjacima smatramo sigurnim za botaničare. Upozorio nas je da težina ovaca ponekad nije dovoljna za aktiviranje mina čime se pobrinuo da potpuno sigurno stignemo u Sarajevo.

Kasnije, od 18. do 24. maja 2003. godine, uspješno je organizirao Treći balkanski botanički kongres u Sarajevu, gdje su botaničari sa Balkana ponovo bili zajedno u Sarajevu i Bosni i Hercegovini, gdje su formirali park balkanskog prijateljstva na Fakultetu prirodnih nauka i matematike. Svi botaničari sa Balkana zasadili su drvo, pa se nadamo da se ovaj park i dalje održava.

Prošli put smo zajedno sa Sulejmanom bili na Žabljaku u Crnoj Gori (19-24.09.20I I.) Na proslavi 50. godišnjice Republičkog zavoda za zaštitu prirode Crne Gore. Tamo smo proveli nekoliko nezaboravnih dana u kojima je Sulejman bio glavni promotor $i$ animator programa te manifestacije.

O Sulejmanu je mnogo rečeno, ali sigurno nije dovoljno u odnosu na to koliko je zaslužio. Imao je toliko energije i ideja tokom predavanja, izleta, projekata i svog društvenog angažmana. Bio je dekan Prirodno-matematičkog fakulteta u Sarajevu, zamjenik ministra u Ministarstvu okoliša Bosne i Hercegovine, član Akademije nauka i umjetnosti Bosne i Hercegovine i drugi.

Sulejman Redžić bio je angažirani intelektualac, patriota, ali prije svega botaničar-ekolog, osnivač Centra za eko- tet u Sarajevu, koji je tokom svog života proučavao jedinstvenu biološku raznolikost Bosne i Hercegovine. Bio je jedan od vodećih balkanskih ekologa, kreativan i neumoran istraživač koji je sazrijevanjem svojih naučnih dostignuća doprinio afirmaciji bosanske i balkanske botaničke nauke na međunarodnoj sceni.

Svojim naučnim radom dao je značajan doprinos poznavanju flore $i$ vegetacije našeg područja, prvenstveno roda Potentilla, Edrianthus, visoko planinske vegetacije, vegetacije suhih travnjaka i šumske vegetacije. Njegova dostignuća predstavljaju značajan doprinos poznavanju flore i vegetacije u širem balkanskom regionu i ostaće dio izvanrednog znanja o biodiverzitetu, gdje će istraživači u regiji i šire biti nadograđivani.

Jedno je sigurno, ljudi poput Sulejmana Redžića vrlo su rijetki. Svi smo ponosni na njegov rad. 